Russell, C. \& Walker, T. K. (1953). J. gen. Microbiol. 8, 310-313.

\title{
Lactobacillus parvus n.sp. Isolated from Beer
}

\author{
By C. RUSSELL AND T. K. WALKER \\ College of Technology, University of Manchester
}

SUMMARY: An organism isolated from a top-fermentation beer was found to be a new heterofermentative species of Lactobacillus. It appears as very small rods of length $1 \cdot 0-1 \cdot 5 \mu$. and width $0 \cdot 8-1 \cdot 0 \mu$. and forms chains. It ferments only glucose, maltose and sucrose and has been named $L$. parvus.

During investigations of lactic acid bacteria which occur as contaminants in breweries and which can cause sourness in beer, Walker \& Parker (1943) isolated thirty-three organisms in pure culture. One of these, provisionally designated $\mathrm{D} 4$, has now been shown to have characteristics markedly different from those of other species of Lactobacillus previously described in the literature.

\section{METHODS}

The behaviour of the organism was observed in the following media: beer, hopped and unhopped, nutrient broth and yeast-extract peptone glucose broth (YEPG). Solid media were prepared by addition of agar or of gelatin to these liquid media. The organism usually does not grow in unhopped brewery wort but occasionally it has shown very feeble development in this medium and in this respect it is unlike many other lactic acid bacteria to be found as infections in yeast and in beer. This is not a $\mathrm{pH}$ effect because the samples of wort used had pH values lying between 4.9 and $5 \cdot 4$ and the organism grows strongly in beer at $\mathrm{pH} 4 \cdot 9-5 \cdot 4$. Wort is probably deficient in a growth factor or factors required by this bacterium. The capacity of the bacterium to ferment carbohydrates was observed in a casein double digest prepared according to the directions of Davis (1939) and supplemented by addition of yeast autolysate $(1 \mathrm{ml} . / 100 \mathrm{ml}$. digest).

\section{DESCRIPTION OF ORGANISM}

\section{Morphological characters}

Shape, size and arrangement of cells: in unhopped beer after $24 \mathrm{hr}$. at $30^{\circ}$ the majority of the cells were $0.8 \times 1.0 \mu$. with some up to $1.5 \mu$. in length and of width $0 \cdot 9 \mu$. Single cells, and chains containing up to twenty cells, were noted. All cells were non-motile.

Staining: the organism was Gram-positive. Attempts to detect capsules, endospores and flagella failed.

\section{Cultural characters}

Observations of growth on solid media were made on cultures which had been incubated in atmospheres of $\mathrm{CO}_{2}$ (85 vol.) plus air (15 vol.). Liquid media after inoculation were incubated in air. In all cases, with the exception of 
growth in beer, which was observed at $30^{\circ}$, and of growth on YEPG gelatin, which was observed at $21^{\circ}$, the temperature of incubation was $25^{\circ}$.

Streak on beer agar after 4 days showed strong growth in the form of opaque, glistening, discrete colonies, of 1-2 mm. diameter. Streak on nutrient agar at 7 days showed slight nodose growth. Streak on YEPG agar at 7 days showed oval and circular discrete colonies of $c .1 .5 \mathrm{~mm}$. diameter and with yellow centres. Stab in YEPG agar after 5 days exhibited strong growth along the line of inoculation, without surface growth. Stab in YEPG gelatin after 5 days: growth was continuous to beaded along the line of inoculation and there was also slight surface growth.

Unhopped beer: at 3 days there was a fair amount of deposit giving rise, when agitated, to a uniform billowy turbidity. Nutrient broth permitted only a weak development of growth, seen at 7 days as a slight deposit, the liquid being clear. Growth in YEPG broth was moderately strong. A deposit separated on the side of the tube and when disturbed set up a non-silky turbidity.

\section{Physiological characters}

Relation to temperature: in unhopped beer the optimum range for growth was $25-34^{\circ}$ with little or no growth below $14^{\circ}$ or above $37^{\circ}$. Relation to oxygen: facultative anaerobe. Relation to $\mathrm{pH}$ value: in unhopped beer optimum $\mathrm{pH}$ value is $5 \cdot 3$; growth does not occur below $\mathrm{pH} \mathrm{4.3}$ or above pH 6.9. Resistance to heat: killed by heating for $15 \mathrm{~min}$. in unhopped beer at $60-65^{\circ}$. Resistance to hop antiseptic: growth markedly restricted by low concentrations $(c .1: 10,000, \mathrm{w} / \mathrm{v})$ of humulone (the principal bacteriostatic constituent of the hop).

\section{Biochemical characters}

Catalase reaction: negative. Acetylmethylcarbinol not formed. Nitrate not reduced to nitrite. Indole not formed. Gelatin not liquefied. Litmus milk not changed.

Carbohydrates utilized. On casein double digest + yeast autolysate, the organism attacked glucose, maltose and sucrose with production of acid, but gas was not detected by Durham tubes. On a xylose medium there was slight growth but acid was not formed. Arabinose, rhamnose, fructose, mannose, galactose, lactose, mannitol, dulcitol, sorbitol, inositol, salicin, inulin, trehalose, raffinose and dextrin were not attacked.

Nature of the acid produced from glucose. The lactic acid formed was converted to acetaldehyde and was estimated as such, after deproteinization of the medium. Another sample of medium was deproteinized, acetic acid separated by distillation in the presence of sulphuric acid and estimated volumetrically. The molar ratio of lactic acid: acetic acid was found to be 100:48. In a later experiment lactic acid was isolated as the zinc salt according to the procedure of Pederson, Peterson \& Fred (1926); the free acid was optically inactive. 


\section{CLASSIFICATION}

Since the organism was rod-shaped, non-motile, non-sporing, Gram-positive, facultatively anaerobic and catalase-negative with ability to ferment carbohydrates but not to reduce nitrate to nitrite, it was placed in tribe Lactobacilleae Winslow et al. of the family Lactobacteriaceae Orla-Jensen. The production of large quantities of lactic acid by the organism further placed it in the genus Lactobacillus Beijerinck.

The organism was compared with species of Lactobacillus described in the literature (Pederson, 1938; Orla-Jensen, 1942; Bergey's Manual, 1948; Shimwell, 1949) and $L$. brevis was found to be the organism which it most resembles. However, the following major differences exist: $L$. brevis is seen as rods $2-4 \mu$. in length, whereas D 4 is seen usually as very short rods about $1 \mu$. long, with some rods up to $1.5 \mu$. in length. In arrangement $L$. brevis occurs as single cells and some small chains, D4 forms definite chains of as many as twenty cells. In gelatin stab the growth of $L$. brevis is filiform while that of D 4 is continuous and beaded. $L$. brevis produces acid in milk and attacks arabinose, xylose, glucose, fructose, galactose and maltose. Usually the attack of $L$. brevis on arabinose is vigorous and occurs with production of gas. D 4 does not produce any change in milk and attacks only glucose, maltose and sucrose, without gas production. We think that these differences are sufficiently large to allow of species differentiation. Accordingly, we propose D 4 as a new species, under the designation $L$. parvus, from the very small size of the cells.

\section{Lactobacillus parvus n.sp.}

Rods, $1 \cdot 0-1 \cdot 5 \mu$. in length, width $0 \cdot 8-0 \cdot 9 \mu$, occurring singly and as chains of as many as twenty rods. Non-motile. Capsules, endospores and flagella not detected. Gram-positive. Colonies on beer agar, nodose, opaque, glistening, 1-2 mm. diameter. Facultative anaerobe. Optimum temperature 25-34${ }^{\circ}$, minimum $14^{\circ}$, maximum $38^{\circ}$. Optimum hydrogen-ion concentration $5 \cdot 3$.

Grows well in unhopped beer and in yeast-extract peptone glucose broth. Growth often appears as a deposit on the side of the tube. Does not grow in most samples of brewers' unhopped wort (a malt-extract solution) or in milk. Attacks glucose, maltose and sucrose with production of acid but not of gas. Has no action on arabinose, rhamnose, fructose, mannose, galactose, lactose, mannitol, dulcitol, sorbitol, inositol, salicin, inulin, trehalose, raffinose and dextrin.

Heterofermentative on glucose media, producing optically inactive lactic acid and acetic acid. Isolated at Manchester from sour beer, March 1942. Subcultures from the type culture have been deposited at the National Collection of Industrial Bacteria, The Chemical Laboratory, Department of Scientific and Industrial Research, Teddington, Middlesex (where its number is NCIB 8516), at the National Institute for Research in Dairying, Shinfield, Reading and at the Laboratories of the Brewing Industry Research Foundation, Nutfield, Surrey. Subcultures have been sent from the National Collection of Industrial Bacteria to the American Collection of Type Cultures. 
The authors desire to thank Dr J. Tosic for assistance in the identification of the new organism.

\section{REFERENCES}

Bergey's Manual of Determinative Bacteriology, 6th ed. (1948). Ed. by BREED, R. S., Murray, E. G. D. \& Hitchens, A. P. London: Baillière, Tindall and Cox.

Davis, J. G. (1939). Practical hints on media in dairy bacteriology. Dairy Ind. 4, $331,360$.

Orla-Jensen, S. (1942). The Lactic Acid Bacteria, 2nd ed. Copenhagen: Ejnar Munksgaard.

Pederson, C. S. (1938). The gas-producing species of the genus Lactobacillus. J. Bact. $35,95$.

Pederson, C. S., Peterson, W. H. \& Fred, E. B. (1926). The forms of lactic acid produced by pure and mixed cultures of bacteria. J. biol. Chem. 68, 151 .

Shrmwelt, J. L. (1949). The lactic acid bacteria (family Lactobacteriaceae). Wallerstein Labs. Commun. 12, 71.

Walker, T. K. \& PArker, A. (1943). The isolation of lactic acid-producing bacteria from beer. J. Inst. Brew. 49, 280.

(Received 2 October 1952) 